\title{
Prinsip Emik dalam Memahami Dinamika Psikologis Pasien Scizophrenia di Jawa
}

\author{
Novita D. Anjarsari \\ Program Magister Profesi Psikologi \\ Fakultas Psikologi Universitas Gadjah Mada
}

\section{Pengantar}

Schizophrenia merupakan salah satu gangguan mental yang banyak dijumpai di berbagai negara. Namun, seringkali prosedur penegakan diagnosis gejala schizophrenia yang didasarkan pada pola pikir dunia barat, menyebabkan penegakan diagnosis tersebut kurang akurat. Jika penegakan diagnosisnya kurang akurat, maka akan berpengaruh pada proses perawatan dan intervensi yang dilakukan terhadap penderita. Kemungkinan terjadinya kesalahan itu dikarenakan sebagian besar dari masyarakat di Jawa tidak menerapkan prinsip emik (memahami fenomena berdasarkan sudut pandang partisipan atau penderita schizophrenia).

Berdasarkan kenyataan yang terjadi, stigma atau labeling negatif dari masyarakat terhadap orang yang mengalami gangguan ini seringkali muncul di berbagai daerah dalam tingkat budaya yang berbeda, walaupun dimanifestasikan ke dalam bentuk yang sangat beragam. Adanya stigmatisasi ini dipandang justru menambah beban psikologis, baik bagi penderita maupun bagi keluarga yang merawatnya. Mereka beranggapan bahwa cap/labeling tersebut telah memupuskan harapan untuk melangsungkan kehidupannya secara normal.

\footnotetext{
${ }^{1}$ Korespondensi mengenai artikel ini dapat melalui: novita_da@mail.ugm.ac.id
}

Dalam salah satu buku trilogi memoar "Aku Tahu Aku Gila", karya Bahril Hidayat Lubis, yang pernah mengalami schizophrenia selama 11 bulan dan tinggal di Jawa, disebutkan bahwa beberapa ilmuwan ternyata memiliki kecenderungan mencatat sebatas apa yang diperoleh dengan berpedoman pada literatur yang sebagian besar berdasarkan pandangan psikologi barat, sehingga kurang memahami fenomena-fenomena yang terjadi dalam diri seseorang. Seperti halnya pengalaman Bahril Hidayat Lubis, terdapat dua hal yang menjadi pukulan berat baginya, yaitu adanya labeling dari luar dikarenakan diagnosis schizophrenia (gila) yang diberikan kepadanya serta kurangnya dukungan sosial dari lingkungan.

Ketika sedang sakit, Bahril Hidayat Lubis dalam mimpinya yang pada akhirnya dapat mengubah seluruh jalan hidupnya. Pada saat itu Bahril Hidayat Lubis bermimpi melihat seorang laki-laki yang berkata: "Barangsiapa menyembah Muhammad, Muhammad telah mati. Barangsiapa menyembah Allah, Allah tidak pernah mati." Mendengar kata-kata tersebut, Bahril Hidayat Lubis menangis dan merasa sedih seta terjadi pergolakan pada dinamika psikologisnya. Karena stigma yang telah terbangun, ia pun mengartikannya sebagai sebuah halusinasi. Terlebih seorang psikiater yang merawatnya membenarkan bahwa mimpi itu bagian dari gejala penyakit yang dideritanya. Kemudian, 
seorang ustadz menjawab, "tidak benar, mimpi itu adalah mimpi yang benar (al-ru'ya ash-shadiqah)". Berawal dari hal tersebut dan juga dukungan sosial dari beberapa orang di sekitarnya, peristiwa berat yang di-alaminya itu telah berlalu dan Bahril Hidayat Lubis kini dinyatakan sembuh dari gangguan mentalnya.

Berangkat dari permasalahan tersebut, pembahasan mengenai penanganan dan penegakan diagnosis terhadap penderita schizophrenia secara lintas budaya, terutama mempertimbangkan aspek budaya Jawa menjadi penting untuk dilakukan.

Dalam kajian lintas budaya terkait dengan abnormal psychology menjelaskan bahwa untuk setiap kasus gangguan abnormal memiliki cara-cara dan pola pemahaman sendiri-sendiri tergantung pada konteks budaya yang dianutnya. Perbedaan tersebut meliputi perbedaan definisi abnormal secara lintas budaya, tingkat perilaku abnormal di masingmasing budaya, pola perilaku yang muncul pada suatu gangguan-gangguan abnormal, pendekatan-pendekatan atau terapi yang digunakan, serta cara mengukur, mengklasifikasikan dan mendiagnosis perilaku abnormal secara lintas budaya.

Scizophrenia merupakan salah satu gangguan psikotik yang ditandai oleh adanya penyimpangan terhadap realita yang ditandai oleh adanya delusi dan halusinasi, penderita menarik diri dari lingkungan atau interaksi sosial, serta munculnya disorganization of perception, thought and emotion.

Hingga detik ini, penyebab utama schizophrenia adalah adanya ketidakseimbangan dopamin penderita. Selain itu ketidakseimbangan yang disebabkan oleh biokimia ini jika didukung oleh dinamika yang kurang sehat dalam keluarga, dimana penderita mengalami kekurangan dukungan sosial, maka keberadaan keluarga justru akan menjadi stressor dan mengakibatkan penderita menunjukkan expression of hostility.

Untuk memahami dan merawat pasien yang mengalami schizophrenia, perlu menggunakan pendekatan cultural framework atau culture specific yang berlaku di daerah tersebut (Stompe dkk., 2006), tidak hanya berdasarkan hasil penegakan diagnosis secara apa adanya menurut kriteria yang ditetapkan. Disamping itu, terdapat juga gangguan-gangguan lain yang hampir mirip dengan schizophrenia dan sangat bervariasi. Akibatnya, proses pendiagnosisan schizophrenia sulit dilakukan jika belum ada batasan yang jelas dengan taraf kepercayaan yang memadai sebelum diagnosis ditegakkan (Waldinger, dalam Versola-Russo, 2006).

Cultural specific juga sangat penting untuk memahami dan melakukan proses tritmen terhadap pasien schizophrenia secara lintas budaya. Besarnya tingkat culture sensitivity (pathoplasticity) tersebut dapat digunakan sebagai estimasi variasi psychotic symptoms pada penderita schizophrenia (delusi, halusinasi, dan first rank symptoms), paling tidak selama dua dekade atau lebih (Stompe dkk., 2006).

Penelitian terkait dengan budaya telah dilakukan oleh International Pilot Studies of Schizophrenia (IPSS) yang diketuai oleh World Health Organization (WHO). Dari penelitian tersebut menunjukkan bahwa penderita schizophrenia di negara berkembang memiliki prognosis yang lebih baik dan terjadi dalam waktu yang lebih singkat. Dari penelitian ini kemudian dikembangkan dalam berbagai macam penelitian yang menguji mengenai peranan budaya dalam membentuk dan merepresentasikan simptom-simptom schizophrenia. Untuk selanjutnya, dengan mendasarkan penelitian-penelitian terse- 
but, Koneru dan de Mamani (2006) menguji lebih lanjut keterkaitan antara tingkat akulturasi dengan tingkat symptoms severity. Dari hasil penelitian tersebut dapat disimpulkan bahwa peningkatan level akulturasi memengaruhi besarnya symptoms severity dari penderita schizophrenia. Meskipun demikian, beragamnya etnis menyebabkan hubungan antara akulturasi dan symptoms severity menjadi sangat kompleks dan bervariasi.

Stigma sosial yang membuat para penderita schizophrenia terdistorsi dalam kehidupannya karena halusinasi, delusi, dan paranoid yang dialaminya, dapat menyebabkan munculnya ketakutan, cemas atau bahkan bingung (VersolaRusso, 2006). Subandi (2007) yang meneliti penderita schizophrenia di Jawa menemukan bahwa orang-orang yang mengalami hilang kontrol yang ditandai dengan bingung diindikasikan sebagai pertanda awal sekaligus sebagai gejala awal psikotis. Fase hilang kontrol terjadi ketika para penderita dengan kriteria first episode psychosis menunjukkan reaksi terhadap pengalaman halusinatif dan delusionalnya sebagai ketakutan dan teror. Penyebab seseorang mengalami kehilangan kontrol dan pemicu gangguan adalah adanya rasa kaget yang mereka alami, baik secara fisik maupun psikologis.

Untuk strategi koping yang dilakukan pun sangat dipengaruhi oleh budaya setempat. Sebagai contoh warga keturunan Brazil cenderung menggunakan sumber daya agama sebagai strategi kopingnya, dimana mereka bersandar pada agama untuk terapi dan menghilangkan ketegangan (Redko, 2003). Hal yang sama juga ditemukan oleh Ruangreangkulkij dan Chesla (2001) yang meneliti perilaku koping pada ibu-ibu keturunan Thailand. Penelitian tersebut menunjukkan bahwa ibu-ibu tersebut memahami bahwa penya- kit merupakan suatu karma (kepercayaan agama Budha) sehingga mereka melakukan thum-jai, yaitu gabungan beberapa sikap seperti penerimaan, sabar, pengertian, tulus, dan rasa tanggung jawab.

Peristiwa yang dialami oleh Bahril Hidayat Lubis, yang telah dipaparkan dapat menjadi contoh bahwa memahami schizophrenia tidaklah cukup hanya dengan menggunakan acuan Data Statistical Manual (DSM) IV atau berdasarkan gejalagejala yang tampak dalam perilakunya, namun juga dengan cara memahami fenomena-fenomena psikologis yang dialaminya. Untuk memahami fenomena psikologis yang terjadi dan menegakkan diagnosis terhadap penderita yang terindikasi mengalami schizophrenia pun sebaiknya tidak mengesampingkan cultural framework yang berlaku di daerah tersebut.

Salah satu cara agar kita tidak mengesampingkan pandangan cultural relativism ini adalah dengan memahami budaya yang berlaku di suatu tempat secara mendalam. Seperti halnya penelitian yang dilakukan oleh Subandi (2007), yang menemukan bahwa pada dasarnya semua penderita schizophrenia memiliki gejala umum sebagai tanda atau gejala awal munculnya psikotik. Akan tetapi istilah yang dipakai seringkali di setiap daerah berbeda, sehingga sangat dimungkinkan perlakuan yang dialami pun akan berbeda. Penemuan ini juga diperkuat dengan penelitian yang dilakukan oleh Koneru dan de Mamani (2006) yang menyimpulkan bahwa tingkat akulturasi yang dialami penderita akan memengaruhi simptomsimptom yang dimunculkannya, yang dalam hal ini adalah seberapa besar peningkatan symptom severity yang terjadi.

Dalam kasus yang menjadi pokok pembahasan ini, perasaan bingung yang muncul dalam diri Bahril Hidayat Lubis dikarenakan stigmatisasi sosial ini meru- 
pakan gejala awal psikotik (first episodic) dalam tingkat yang masih ringan. Pengalaman psikotik ini dapat digambarkan sebagai suatu bentuk hilangnya kontrol, yang dalam penjelasan beliau disebutkan bahwa Bahril Hidayat Lubis melakukan segala sesuatu di bawah kesadaran.

Jika dilihat berdasarkan gejala yang dialaminya, terdapat kemungkinan yang sangat besar untuk sembuh. Terlebih jika ada dukungan sosial dan pendampingan dari lingkungan sekitar, gangguan yang berada dalam level ini cenderung dapat disembuhkan. Dengan adanya dukungan sosial yang kuat, emosi dan ketegangan yang dialami oleh penderita akan terjaga dan mendorongnya untuk mencapai kehidupan yang lebih berkualitas (tenteram dan damai).

Namun, diagnosis yang menyatakan bahwa beliau gila, cenderung menambah beban psikologis yang dialaminya, karena hal tersebut membuatnya dikucilkan dan diperlakukan secara negatif. Oleh karena itu, suatu hal yang wajar bila beliau memandang bahwa orang-orang lain hanya melihat berdasarkan apa yang dilihat dan dikatakan orang, bukan memandang dinamika psikologis yang ada dalam dirinya.

Estimasi variasi simptom yang dapat dimunculkan pun sangat mungkin dipengaruhi oleh budaya (Stompe dkk., 2006). Dalam masyarakat Jawa, istilah-istilah untuk menyebutkan gangguan abnormal sangat banyak dan berdasarkan tingkatan yang berbeda, yaitu kasar dan halus. Istilah yang kasar, cenderung menyiratkan bahwa gangguan yang dideritanya sangat parah dan cenderung tidak dapat disembuhkan. Penyebutan gangguan mental yang dianggap kasar tersebut antara lain edan, sinting, gendeng, dan kenthir. Dalam bahasa Indonesia diterjemahkan dengan istilah "gila". Sedangkan untuk yang halus cenderung dapat difungsikan sebagai bentuk penghindaran stigma (Subandi, 2007) dan mengindikasikan bahwa gangguan yang dideritanya masih dimungkinkan untuk sembuh. Penyebutan gangguan mental yang dapat dikategorikan sebagai istilah halus antara lain sarap (syaraf), miring, ora genep (hilang akal), dan bingung. Dengan demikian dapat dikatakan bahwa pada dasarnya penggunaan istilah yang berbeda (menyesuaikan tingkatan bahasa dalam budaya Jawa) akan menimbulkan tingkat variasi simptom yang berbeda pula. Jika dikaitkan dengan kasus Bahril Hidayat Lubis, penyebutan istilah "gila" dimungkinkan menjadi penyebab meningkat atau makin parahnya simptom yang dialami karena istilah tersebut cenderung mendorong ia meyakini bahwa sakit yang dideritanya tergolong degeneratif dan berlangsung seumur hidup. Hal ini juga terindikasikan dalam efek stigma yang dirasakan sebagai pukulan berat karena penyebutan istilah tersebut.

Pembedaan istilah-istilah lokal ini tentunya tidak dikaji dalam kriteria DSM IV yang dibuat oleh ilmuwan barat, karena permasalahan ini tergolong permasalahan emik. Oleh karena itu, meskipun untuk menegakkan diagnosis schizophrenia didasarkan pada kriteria yang telah dibuat, namun sebaiknya permasalahan emik ini juga dipertimbangkan, sebab menyangkut kualitas hidup seorang manusia. Jika penggunaan diagnosis emik dipandang memiliki stigma yang lebih ringan dalam menggambarkan sebuah simptom yang dimunculkan penderita, hal tersebut dapat pula dijadikan sebagai alternatif dalam penegakan diagnosis agar beban psikologis yang dirasakan oleh penderita maupun pihak keluarganya tidak semakin berat. Sebagai contoh, penggunaan istilah "bingung" atau "sakit" dan sejenisnya, dibandingkan dengan istilah "gila" atau 
"schizophrenia", label ini juga dirasa lebih positif.

Disamping dukungan sosial dari lingkungan sekitar, strategi koping yang digunakan pun sangat berpengaruh terhadap perkembangan gangguan mental yang dialaminya. Di beberapa daerah atau budaya tertentu terdapat kecenderungan untuk menggunakan agama atau pendekatan religiusitas sebagai strategi kopingnya. Dalam kasus ini, untuk menangani permasalahan Bahril Hidayat Lubis, pendekatan yang digunakan cenderung mendasarkan pada agamanya dan menggunakan pendekatan religiusitas. Kebetulan agama yang dianut Bahril Hidayat Lubis adalah Islam yang berbeda dengan pandangan di barat. Dalam ajaran Islam, setiap manusia dilahirkan dengan kebaikan dan dalam keadaan fitrah, sehingga bisa jadi munculnya gangguan tersebut dikarenakan faktor situasional. Keluarga dan orang-orang di sekelilingnya yang berprinsip demikian, membuat Bahril Hidayat Lubis merasa didampingi dan berhasil keluar dari permasalahan yang dialaminya. Jadi, meskipun penegakan diagnosis yang cenderung memandang negatif suatu gangguan (didasarkan pada DSM IV yang mengarah pada prinsip universalitas), namun jika penanganan dan cara perawatannya mendasarkan prinsip emik, dimungkinkan penanganan yang dilakukan lebih efektif karena sesuai dengan konteks budaya dan agama yang dianutnya. Hal ini didasari adanya asumsi bahwa tidak semua intervensi atau penanganan di salah satu budaya dapat diterapkan di semua budaya.

Dengan demikian, sebaiknya teoriteori yang berdasarkan pandangan barat, sebaiknya disaring dan disesuaikan dengan budaya di Indonesia. Jika terdapat teori yang relevan dengan budaya kita maka tidak ada salahnya diterapkan, na- mun jika tidak dapat diterapkan, sebaiknya menggunakan alternatif lain, terlebih dalam kasus ini menyangkut penegakan diagnosis terhadap suatu gangguan. Penegakan diagnosis yang salah atau kurang tepat, intervensi yang diberikan pun akan diragukan keberhasilannya, bahkan kemungkinan yang terjadi adalah memperparah kondisinya.

\section{Penutup}

Dari pembahasan yang telah dilakukan dapat disimpulkan bahwa disamping aspek universalitas, terdapat pula aspek culture specific yang digunakan dalam menegakkan diagnosis dan menangani pasien dengan gangguan schizophrenia agar kita dapat mengetahui dinamika psikologis, memahami pasien berdasarkan sudut pandangnya (pendekatan emik) dan mempertimbangkan aspek budaya atau agama yang dianutnya. Untuk menangani pasien schizophrenia di Jawa perlu memperhatikan penggunaan tingkatan (strata) bahasa yang berlaku dalam masyarakat tersebut, sebab penggunaan istilah yang berbeda akan memberikan dampak psikologis yang berbeda sekaligus sebagai salah satu bentuk dukungan sosial bagi pasien dengan kriteria first episodic psychotic.

\section{Daftar Pustaka}

Cohen, A. (1992). Prognosis for schizophrenia in the third world: reevaluation of cross-cultural research. Culture, Medicine, and Psychiatry, 16, 53-75.

Koneru, V. K., \& de Mamani, A. G. W. (2006). Acculturation, ethnicity, and symptoms of schizophrenia. Revista Interamericana de Picologia/Interamerican Journal of Psychology, 40(3), 355-362. 


\section{PRINSIP EMIK, PSIKOLOGIS PASIEN SCIZOPHRENIA}

Matsumoto, J. (2008). Culture and Psychology.

Redko, C. (2003). Religious construction of a first episode of psychosis in Urban Brazil. Transcultural Psychiatry, 40(4), 507-530.

Stompe, T., Karakula, H., Rudaleviciene, P., Okribelashvili, N., Haroon R. Chaudhry, H. R., Idemudia, E. E., \& Gscheider, S. (2006). The pathoplastic effect of culture on psychotic symp- toms in Schizophrenia. World Cultural Psychiatry Research and Review, 1(3/4), 157-163

Subandi. (2007). Dimensi psikokultural dalam pengalaman psikotik. Jurnal Psikologi 34(1), 40-54.

Versola-Russo, J. (2006). Cultural and demographic factors of schizophrenia. International Journal of Psychosocial Rehabilitation, 10(2), 89-103. 